\title{
Student Engagement, Retention, and Motivation: Assessing Academic Success in Today's College Students
}

\author{
Gail D. Caruth* \\ Department of Higher Education and Learning Technologies, Texas A\&M University@
} Commerce, United States

\begin{tabular}{|c|c|}
\hline Article history & Despite the attention given to student retention for nearly half a \\
\hline $\begin{array}{l}\text { Received: } \\
16.05 .2018\end{array}$ & $\begin{array}{l}\text { century, college graduation and persistence rates have not } \\
\text { improved in over two decades. Furthermore, time to degree rates }\end{array}$ \\
\hline $\begin{array}{l}\text { Received in revised form: } \\
23.05 .2018\end{array}$ & $\begin{array}{l}\text { suggest that it is taking more time to earn degrees. Consequently, } \\
\text { there is a significant amount of individual and financial expense } \\
\text { required to earn a college degree. Higher education has the }\end{array}$ \\
\hline $\begin{array}{l}\text { Accepted: } \\
15.05 .2018\end{array}$ & $\begin{array}{l}\text { responsibility to the society it serves to make postsecondary } \\
\text { education a successful experience for students. Is higher }\end{array}$ \\
\hline Key words: & education measuring up to meet the learning needs of society? \\
\hline $\begin{array}{l}\text { Assessments; student } \\
\text { assessments; college } \\
\text { assessments; student success; } \\
\text { student engagement; student } \\
\text { motivation }\end{array}$ & $\begin{array}{l}\text { The purpose of this paper was to examine academic success of } \\
\text { today's college students. It is important to know if students are } \\
\text { graduating from college. Determining whether or not colleges } \\
\text { and universities are meeting the learning needs is critical for } \\
\text { higher education. This research study was an archival } \\
\text { quantitative, data mining study using data from the Integrated } \\
\text { Postsecondary Education Data System (IPEDS) of the National } \\
\text { Center for Education Statistics. This study identified the } \\
\text { graduation numbers during the years } 2009 \text { to } 2014 \text { according to } \\
\text { available data at public, private, and for-profit } 2 \text {-year and } 4 \text {-year } \\
\text { universities in the United States. Findings revealed that for-profit } \\
\text { 2-year and 4-years institutions saw the greatest increase in } \\
\text { institutions and students graduating from } 2009 \text { until } 2014 \text {. }\end{array}$ \\
\hline
\end{tabular}

\section{Introduction}

Student engagement is fundamental for student success in college (Fredin, Fuchsteiner, \& Portz, 2015). Student engagement is a concept that is approximately threequarters of a century old and refers to how engrossed or attentive students seem to be in their learning or how integrated they are with their classes, colleagues, and colleges. The measure of student engagement is considered a defensible gauge of academic distinction and carries more weight than the size of the college library (Axelson \& Flick, 2011).

Historically, to engage oneself was widely accepted as an oath, promise, or guarantee of something. Engagement was consequently an ethical, principled, moral, even lawful responsibility. Over time engage has softened to translate more toward an interest in,

*Correspondence: gaildianna@flash.net 
attentiveness to, concentration on, or an awareness of something. Hence, students are engaged when they are listening carefully and paying attention in the classroom (Axelson \& Flick, 2011).

Who then is responsible for student engagement? This is where more research is needed. According to Axelson and Flick (2011), the answer could be students, instructors, or cultures. Furthermore, this question could be debated indefinitely without reaching a consensus. A more appropriate question should be to ask about the aspects that impact student engagement during the learning process, as maintained by Axelson and Flick.

Korobova and Starobin (2015) claimed that international students were more engaged than American students due to inspiring and supportive experiences and interactions with colleagues. They also claimed that international and American students experience similar student satisfaction and overall academic success. There are five yardsticks for predicting student satisfaction and academic success, which are the (a) degree of course demands, (b) depth of student-faculty relationships, (c) level of inspirational scholastic experiences, (d) quality of a helpful atmosphere, and (e) intensity of a caring college environment. Accordingly, it can be expected that the more students are integrated with a college, the higher the degree of student satisfaction and academic success. Furthermore, student success is linked to student engagement, as maintained by Korobova and Starobin.

In spite of the ongoing focus on student retention for over four decades, college graduation and persistence rates have not improved over the past 20 years. Furthermore, time to degree rates indicate that it is taking more time rather than less time to earn degrees. As a result, there is a considerable amount of individual and financial expense needed to earn a college degree. Ongoing attention in higher education on enhancing student success is prompted by monetary responsibilities. Attempts to recognize and increase retention rates are also reasonable in light of the need for earning a degree. Earning a college diploma is tied to students' commitment to their college and the level of commitment to their college is tied to students' level of campus social and academic integration. Slanger, Berg, Fisk, and Hanson (2015) claimed that there are four variables for predicting academic success and retention, which are (a) secondary educational performance, (b) demographical and socio-economical characteristics, (c) collegial integration, and (d) institutional support, financial aid conditions, and overall quality of instruction. According to Slanger et al. (2015), student motivation seems to be linked to both academic success as well as college persistence.

Designing a paired course intervention for under-prepared college students features a dual instructional method of academic skill building and lifelong learning development to encourage students to do more academically and to become lifelong learners. In a reading course, for example, students enhanced their reading ability and used the new reading ability in the paired course. Students gained lifelong learning characteristics. Shaffer, Eshbach, and Santiago-Blay (2015) claimed that it is the whole college encounter, the overall college experience, and the personalized student experiences both in and out of class that has a significant impact on college success.

The incorporation of writing assignments and activities in writing and non-writing courses can enhance student writing because it is thought that writing is thinking. Therefore, writing assignments and activities have a positive effect on learning and engagement. Colleges and universities are increasingly allocating sources for incorporating writing initiatives in the classroom. In addition, institutions have designed quality enhancement programs to focus on 
student needs and to require students to complete a writing course for this reason. Huskin (2016) encourages teachers to support student writing initiatives in their classes regardless of whether or not they are qualified to teach college level writing courses.

Higher education is conscious of the need for learning. Student learning in colleges and universities is assessed through a number of variables. These variables may indicate the amount of learning that was achieved but they do not address the students' ability to change. Change is inevitable and is necessary for students for to be able to develop into whom students would like to become. Likewise, Sternberg (2015) maintained that higher education overall needs to learn to be able to change in order to be prepared for the future. Confronted with the stress of guaranteeing admission and financial cutbacks in conjunction with criticisms over escalating educational costs and student debt, institutions have changed their attention to discovering more appropriate budgeting procedures (Ribando, \& Evans, 2015). Unfortunately, changes are challenging and complicated. Change is not easily accomplished (Sternberg, 2015).

As a result of the burgeoning and ubiquitous change initiatives confronting the academy, all institutions of higher education need to learn to keep up to be able to meet the learning needs of the society it serves. Is higher education measuring up to meet these needs? The purpose of this paper was to examine graduation rates of today's college students. The study is significant for determining if colleges are successful with meeting the learning needs of the society it serves. Ascertaining whether or not colleges are meeting the learning needs is critical for higher education. Colleges have the duty to society to make postsecondary education a successful experience for students to be able to do well in school and to become what they want to become. It is important to know if students are graduating from college.

A review of the literature presents a compilation of research, peer-reviewed journals, non-peer reviewed journals, books, and online sources on today's college students. The academic databases used were from the online library of Texas A\&M University-Commerce and included, but were not limited to, Academic Search Premier, EBSCO, Education Research Complete, Eric, ProQuest, and Sage Publications. The key descriptive terms used for this research were assessments, student assessments, college assessments, academic success, student success, student engagement, student motivation.

\section{Review of the Literature}

The body of literature is replete with verification of the value of a college education. "Graduation pays" (Strayhorn, 2015, p. 56). According to the United States Department of Education, National Center for Education Statistics (2015) the median annual earnings of young adults, ages 25 to 34, with less than a high school degree was $\$ 23,200$ for 2012 and $\$ 23,900$ for 2013; with a high school degree was $\$ 30,400$ for 2012 and $\$ 30,000$ for 2013; and with a bachelor's degree was $\$ 50,700$ for 2012 and $\$ 50,000$ for 2013. Also, the unemployment rates of young adults, ages 25 to 34, with less than a high school degree was $51.1 \%$ for 2012 and $13.7 \%$ for 2013; with a high school degree was $12.1 \%$ for 2012 and $10.5 \%$ for 2013; and with a bachelor's degree was 3.6\% for 2012 and $3.7 \%$ for 2013 .

Also according to the United States Department of Education, National Center for Education Statistics (2015), the retention rates were $79 \%$ for years $2011-12$ and $80 \%$ for years 2012 2013 in 4-year institutions while 59\% for years 2011-12 and 60\% for years 2012-2013 in 2year institutions. The actual graduation rates were only $59.2 \%$ for years $2011-12$ and $59.4 \%$ for years 2012-2013 in 4-year institutions while 31\% for years 2011-12 and 29\% for years 
2012-2013 in 2-year institutions. Therefore, retention rates can not be the means for assessing college or student success. If higher education assesses college or student success according to retention numbers and rates only, then there is no incentive to ensure that students actually earn a degree (Strayhorn, 2015).

Those in higher education are dedicated to teaching excellence. Assessments are in position at all stages and approaches of learning to guarantee success, such as a mixture of program, curriculum, course and instructor, and student learning outcomes assessments. These assessments involve student, colleague, and expert responses and critiques by means of observing, testing, evaluating electronic portfolios, completing questionnaires, etc. (Andrade, 2015).

\section{Assessing College Success}

These are chaotic times for colleges due to more and more incoming students being placed into developmental courses, the governmental concentration on completion rates, and the ubiquitous risk of financial cutbacks. Assessing the success of a college, or lack of success, is most often completed through student retention rates. Conversations regarding successful retention and graduation numbers and rates often become remorseful and sorrowful. Ostensibly, able students drop out from college to care for family members, pay the bills, separate from bad grades, or accept defeat due to falling behind. Ascertaining what changes are needed to achieve improved completion rates is dependent upon a research methodology and administrative attitudes that searches not only numbers and rates of retention and graduation but the contributions of successful students, as maintained by Trucker (2014).

Graduation rate from (a) first institution attended within 150 percent of normal time for firsttime, full-time degree or certificate-seeking students at 2-year postsecondary institutions by selected cohort entry years 2000 through 2010 in public, private, and for-profit universities in the United States and (b) first institution attended for first-time, full-time bachelor's degreeseeking students at 4-year postsecondary institutions by selected cohort entry years 1996 through 2007 at public, private, and for-profit universities in the United States can be seen in Table 1, as calculated by the Integrated Postsecondary Education Data System (IPEDS) of the National Center for Education Statistics (National Center for Education Statistics, (2014a, b). IPEDS is a system of interrelated surveys compiled each year by the National Center for Education Statistics. IPEDS gathers information from colleges, universities, and technical and vocational institutions that are involved in federal student financial aid programs. The Higher Education Act of 1965, as amended, requires institutions that are involved in federal student aid programs to submit data on enrollment, program completion, graduation rates, faculty and staff, finances, institutional prices, and student financial aid (The Higher Education Act of 1965). These data are made available to the public through the IPEDS Data Center. IPEDS reported the data shown in Table1. 
Table 1. Graduation Rates from first institution attended for first-time at 2-year and 4-year Institutions

\begin{tabular}{|c|c|c|c|c|c|c|c|c|}
\hline $\begin{array}{c}\text { Cohort } \\
\text { Year }\end{array}$ & $\begin{array}{l}\text { 2-yr Total } \\
\text { Institutions }\end{array}$ & $\begin{array}{l}\text { 2-yr Public } \\
\text { Institutions }\end{array}$ & $\begin{array}{c}2-y r \\
\text { Private } \\
\text { Institutions }\end{array}$ & $\begin{array}{c}2 \text {-yr } \\
\text { For-Profit } \\
\text { Institutions }\end{array}$ & $\begin{array}{l}\text { 4-yr Total } \\
\text { Institutions }\end{array}$ & $\begin{array}{l}\text { 4-yr Public } \\
\text { Institutions }\end{array}$ & $\begin{array}{l}\text { 4-yr Private } \\
\text { Institutions }\end{array}$ & $\begin{array}{c}\text { 4-yr } \\
\text { For-Profit } \\
\text { Institutions }\end{array}$ \\
\hline 1996 & & & & & 33.7 & 26.0 & 48.6 & 21.8 \\
\hline 1997 & & & & & & & & \\
\hline 1998 & & & & & & & & \\
\hline 1999 & & & & & & & & \\
\hline 2000 & 30.5 & 23.6 & 50.1 & 59.1 & 36.1 & 29.0 & 50.3 & 25.7 \\
\hline 2001 & 29.3 & 21.9 & 49.1 & 57.1 & & & & \\
\hline 2002 & 29.1 & 21.5 & 49.0 & 57.2 & 36.4 & 29.9 & 51.0 & 14.2 \\
\hline 2003 & 27.8 & 20.3 & 44.4 & 58.2 & 37.0 & 30.7 & 51.6 & 14.8 \\
\hline 2004 & 27.5 & 20.6 & 48.2 & 57.7 & 38.0 & 31.4 & 52.6 & 20.6 \\
\hline 2005 & 29.2 & 20.4 & 52.8 & 58.3 & 38.3 & 32.0 & 52.2 & 20.0 \\
\hline 2006 & 29.8 & 20.3 & 51.0 & 60.6 & 39.0 & 32.8 & 52.9 & 22.8 \\
\hline 2007 & 31.2 & 20.2 & 56.6 & 61.7 & 39.4 & 33.5 & 52.8 & 22.5 \\
\hline 2008 & 31.0 & 19.8 & 62.3 & 62.8 & & & & \\
\hline 2009 & 30.5 & 19.5 & 53.6 & 62.8 & & & & \\
\hline 2010 & 29.4 & 23.6 & 50.1 & 59.1 & & & & \\
\hline
\end{tabular}

Table 1 indicates from the graduation rates that 2-year institutions have experienced some fluctuation between the years 2000 to 2010 but remained the same overall or experienced minimal decline (total institutions experienced nearly a one percent decline). However, the graduation rates at 4-year institutions have experienced some improvement overall of approximately three percent, except the for-profit institutions that realized close to a three percent decline.

College honors programs are major impellent powers in depicting college success, as suggested by Johnson (2015). Honors programs assist colleges in identifying and nurturing the best and brightest students. These students, for example, earn national and international recognition for themselves and their respective colleges through the awards of prominent scholarships. They also earn recognition through first-rate academic success and surpassing what is expected of them. Honors students graduate with the knowledge and know-how that prepares them for on the spot employment or acceptance into the finest graduate programs. These assessment outcomes result in tangible and intangible benefits for colleges and students.

Mahlberg (2015) claimed that using formative assessments enhance academic success. Assessments are important for learning. Successful learning in the classroom requires the ability to assess effectively student learning. Also, the ability to self-regulate is essential for academic success in higher education and at the office. Additionally, intercessions in the classroom can positively impact self-regulation. Student grades have been improved in courses where the emphasis was on student learning and enthusiasm for learning.

College freshman and sophomores tend to employ self-regulated learning when also taking courses involving opportunities for self-assessing performance on learning and self-modifying performance using internal cognitive, affective, and behavioral management. These students manage reading and goal setting more effectively. Self-regulation positively impacts student's course management, success, engagement, retention, grades, and enhances the number of credit hours taken in future semesters (Mahlberg, 2015).

Formative self-assessments are a means for increasing self-regulation in college students. In turn, the ability to self-regulate has a positive effect on academic success. Students who complete self-assessments in their college classes demonstrate improved self-regulation, 
which includes behavior of "coming to class prepared, setting goals, reflecting on learning objectives, and modifying study strategies to increase understanding" (Mahlberg, 2015, p.779). Hence, the use of self-assessments compels students to cultivate cognitive and behavioral engagement, as claimed by Mahlberg. Students who are engaged in their classes, moreover, may not be conscious of the effort invested in a course until completing a selfassessment on themselves and their learning. By encouraging the development of metacognitive thinking in students through self-assessments of their own performance leads to student retention at little or no cost to students or colleges, as further claimed by Mahlberg.

Formative types of assessments have been used in employment with action steps that employees can achieve. These assessments include measures from various viewpoints for a complete picture; measures of various objectives and end goals; measures of various steps that build upon each other; and measures of various dates for feedback and modifications. Colleges have also used this type of assessment for managing targets and faculty performance. While a checklist of courses to be taken and program requirements to complete convey the program to students, a checklist does not illustrate how the steps and requirements are interrelated. In addition, by completing a program checklist automatically suggests that students appreciate the connection of their academic engagement to their academic success. Fredin et al., (2015) indicated that formative type of assessments can also enhance student engagement, which leads to student success.

\section{Assessing Student Success}

Student success, or assessing student learning outcomes in colleges, has been given national and global interest. A major aspect of these assessments, both nationally and globally, is that the results of assessments and utilization of the results generally remain only within the department, program, or discipline even though the results may have important consequences for colleges as a whole. The results and utilization of these assessments, therefore, end up having no benefit for the students. It is for that reason that students' motivation for taking assessments becomes problematic and the lack of follow through of these assessments leads to questions of reliability and validity (Liu, Rios, \& Borden, 2015).

Student characteristics, such as direction, determination, and dedication are important for student success. Students with direction, determination, and dedication tend to have larger semester loads, which in turn leads to graduating. On the other hand, students who are under stress do not attend class (Stelnicki, Nordstokke, \& Saklofske, 2015; Stephan, Davis, Lindsay, Miller, \& American Institutes for Research, National Center for Education Evaluation and Regional Assistance, \& Regional Educational Laboratory Midwest, 2015), procrastinate, and have interruptions in the education which leads to not graduating (Stelnicki et al., 2015).

Liu et al. (2015) maintained that (a) motivational teaching notably enhances students' motivation for test-taking and receiving test grades; (b) students with higher test-taking motivation continually invest greater amounts of time responding to questions and leave less questions unanswered; and (c) unmotivated students can be identified by the amount of time they take to answer each question. Therefore, college teachers are encouraged to work to enhance student motivation prior to giving student assessments and to remove the test scores from unmotivated students once signs of a lack of motivation are apparent.

The two words, student success, when combined have grown to become crucial in assessing success in higher education. Student success starts with admission. Students who want a college education, should have access to an education. "Access without success is useless, but 
access with success is everything" (Strayhorn, 2015, p. 58). For students to succeed academically they must accept that there (a) is a culture in higher education; (b) are many traditions, beliefs, and a secret code or language filled with acronyms associated with academia; (c) are rules for behavior, way of life, standards, verbal communication, necessities, regulations, and mores that academic advisors or navigators understand; and (d) is a proper means for obtaining a sense of belonging and being cared about through community relations, associations, and interactions on college campuses. Academic advisors or navigators help students succeed academically by navigating the college experience, making the unspoken spoken, and feeling a sense of belonging and that they are a part of the college community.

Research indicates that there is a connection between mindfulness, "specific practices used to focus a person's attention" (Leland, 2015, p.19), and student success. Mindfulness in education seems to have an encouraging influence on student success by assisting students' with engaging, organizing, planning, performing, and thinking critically. Students skilled in mindfulness are more apt to conduct themselves according to the college standards. Mindfulness is valuable in all programs, for all ages, and for levels of students. During a time of budgetary cutbacks, including mindfulness teaching in the classroom can be completed at minimal or at no cost. Including mindfulness teaching can also be incorporated into the curriculum in current classes or as a new class. Assessments of incorporating mindfulness teaching into the college curriculum results in improved "skills in focus, problem-solving, impulse control, relationship-building, and stress reduction" (p. 23).

\section{Assessing Teaching Success}

Pinpointing successful teachers and teaching has motivated a great amount of academic exploration during the past 100 years. Thus far, consensus of what constitutes successful teachers and teaching has been difficult to pin down. Also, teachers vary in success leading to a disparity of achievements. Years of investigation, however, continually suggest that there is a clear association linking first-rate teaching to student success. Furthermore, particular teaching approaches are more successful than others and teachers differ in the employment of those approaches (von der Embse \& Putwain, 2015).

There has been a reliance on student test performance for assessing teachers. Student test performances have been widely used due to the disparity of teaching and the lack of valid instruments for assessing teaching (von der Embse \& Putwain, 2015). Furthermore, student test grades are currently utilized for rating teachers for tenure, career advancement, compensation, recognition, and employment decisions (Dodeen, 2013; von der Embse \& Putwain, 2015). Test performance grades may be impacted by variables other than teaching, as cautioned by von der Embse and Putwain (2015). The use of test performance grades, moreover, has been criticized for creating student and teacher stress as well as unsuccessful teaching in the classroom.

Teacher successfulness is a blend of individual abilities, comprehending learning theories and subject matter, being able to change teaching methods, and working in partnership with colleagues. In contrast, teaching successfulness is teaching that encourages learning by meeting students where students are and by meeting students' needs. Teaching successfulness is both teacher successfulness and providing a successful teaching environment. In other words, one must consider the context of teaching to be able to assess teaching successfulness. Successful teachers, for example, may undertake substandard practices when confronted with 
pressures to increase test scores, as maintained by von der Embse and Putwain (2015). Scholars have pinpointed the strength of the teacher-student relationship and psychological support received from administrators as leading to academic success.

According to von der Embse and Putwain (2015), it is important to consider the context of teaching for enhancing student achievement. The context in which teachers teach is complicated, multifaceted, and entails procedural judgments. Also, in spite of the variety of teaching approaches there are similarities that may band together successful teaching in the classroom. Additionally, the use of specific teaching approaches and student reactions to the various approaches are a matter of and subject to individual judgments. In addition to individual judgments, there are common judgments of effective teaching making the assessment of teaching and student evaluations of teaching complicated.

Assessing teacher effectiveness is typically completed through student evaluations of teaching and in some cases it is the only means for assessment of instructional quality. These assessments are summative in nature and are beneficial for training and development, as well as curriculum initiatives. The assessment instrument itself normally corporates a Likert-type rating scales with some open-ended questions. The ratings cover "teaching methods, knowledge, organization, interaction with students, clarity, effective communication, grading, using technology, flexibility, enthusiasm, valuable feedback, fairness of grades, rapport with students, personal characteristics, preparation, availability of instructor outside the classroom, workload, interesting presentations, and clarifying difficult points" (Dodeen, 2013, p. 2). On the other hand, the ratings do not normally cover what cannot be seen by students, such as "course design, quality of readings, academic standards, and quality of assignments" (p. 2). The open ended questions provide opportunities for students to make note of any recommendations. The rating scale is however, the fundament component. Dodeen claimed that assessment instruments can be utilized across disciplines and are not course specific.

\section{Student Perceptions of Student Assessments}

Student perceptions of how they will be assessed may affect how they study, their interest in learning, their expectations, and their educational accomplishments. Therefore, Doménech-Betoret and Fortea-Bagán (2015) maintained that it is essential for teachers to find out how students perceive they will be assessed early in the semester. Finding out how students perceive they will be assessed is essential so that teachers can address any concerns or questions in order to alleviate any potential problems and to correct incorrect perceptions. Finding out student perceptions will provide opportunities to impact student contentment and learning. In addition, finding out about student perceptions early can minimize any test anxiety and result in more positive learning outcomes (Betoret \& Fortea-Bagán, 2015; Contreras-Higuera, Martínez-Olmo, Rubio-Hurtado, and Vilà-Baños, 2016; Stelnicki et al., 2015; Zapata, 2016). Feedback from students corroborates the value of finding out about their perceptions regarding assessments (Zapata, 2016).

Contreras-Higuera et al., (2016) maintained that student perceptions of electronic portfolios, for example, are not very hopeful. This is particularly true with students who are using them for the first year. Students tend to be frustrated due to not understanding how to select the appropriate artifacts, knowing how to organize the electronic portfolio, being able to finish the electronic portfolio by the due date, and comprehending how to utilize electronic portfolios. Bearing in mind that student perceptions of electronic portfolios may affect how they study electronic portfolios, their interest in learning about electronic portfolios, their 
expectations of electronic portfolios, and their educational accomplishments regarding electronic portfolios (Betoret \& Fortea-Bagán, 2015; Contreras-Higuera et al., 2016; Stelnicki et al., 2015; Zapata, 2016). Therefore, teachers are encouraged to teach students about selecting appropriate artifacts, organizing electronic portfolios appropriately, effective time management, and demonstrate what an electronic portfolios is by providing examples of completed electronic portfolios for student to examine (Contreras-Higuera et al., 2016).

On the other hand, Contreras-Higuera et al., (2016) maintained that student perceptions of rubrics were encouraging. Students tend to view rubrics as a valuable aide for providing a general idea for guiding assignment preparation. Students felt that rubrics are helpful for communicating competences and for bringing about transparency with student assessments.

Additionally, students' perceptions of taking out a loan to pay for an education are influenced by their peers, parents, school counselors, and teachers. McKinney, Mukherjee, Wade, Shefman, and Breed (2015) maintained that most college-age students have positive thoughts and perceptions about using credit to obtain their degrees. However, students with pessimistic thoughts and perceptions about acquiring debt to pay for a college degree can lead to a negative impact on their emotional welfare and results in leaving college for employment.

When assessing the use of loans to fund a college education, McKinney et al.., (2015) claimed that college students do not fully take into account the outcomes of borrowing and repaying college debts. College students forced to borrow funds often lack the knowledge of the obligations from this financial decision. Many students would be unable to enrol in college without these loans. Moreover, students often rely on this money to fund their transportation costs to and from class. By taking out college loans students can work reduced hours at a job, invest more time with their studies, and become more integrated in college activities. College loans ought to enhance, not worsen, a students' economic position. According to the United States Department of Education, National Center for Education Statistics (2015), the average student loan amount was $\$ 6,900$ for the years 2011-2012 and \$7,000 for the years 2012-2013. The loan default rates were $14.7 \%$ for the fiscal year 2010 and $13.7 \%$ for the fiscal year 2011 .

In summary, a review of the literature revealed that: (a) retention rates are the measure used most often for assessing college success; (b) retention numbers and rates does not provide incentive for graduating students; (c) assessments are important and requires the ability to assess effectively student learning; (d) self-regulation is essential for academic success; (e) formative self-assessments increase self-regulation which is linked to student success; (f) mindfulness is connected to student success; (g) pinpointing successful teachers and teaching is difficult; (h) first-rate teaching is linked to student success; (i) particular teaching approaches are more successful than others and teachers differ in the employment of these approaches (j) student test performance has been used for assessing teachers even though the practice has been criticized; $(\mathrm{k})$ teacher successfulness is a blend of individual abilities with comprehending learning theories and subject matter, being able to change teaching methods, and working in partnership with colleagues; (l) teaching successfully is teaching that encourages learning by meeting students where students and meeting students' needs; (m) assessing teacher effectiveness is typically completed through student evaluations of teaching and in some cases it is the only means for assessing instructional quality; and (n) student perceptions of how they will be assessed may affect how they study, their interest in learning, their expectations, and their educational accomplishments. 


\section{Method of Procedure}

This research study was an archival quantitative, data mining study using data from the Integrated Postsecondary Education Data System (IPEDS) of the National Center for Education Statistics (National Center for Education Statistics, 2014). IPEDS is a system of interrelated surveys compiled each year by the National Center for Education Statistics. IPEDS gathers information from colleges, universities, and technical and vocational institutions that are involved in federal student financial aid programs. The Higher Education Act of 1965, as amended, requires institutions that are involved in federal student aid programs to submit data on enrollment, program completion, graduation rates, faculty and staff, finances, institutional prices, and student financial aid (The Higher Education Act of 1965). These data are made available to the public through the IPEDS Data Center.

This study identified the graduation numbers during the years 2009 to 2014 according to available data at public, private, and for-profit 2-year and 4-year universities in the United States. Data were extracted according to institution type in public, private, and for-profit 2year and 4-year universities in the United States. The data were downloaded from IPEDS and converted into an Excel document. The Excel document was formatted and cleaned up.

\section{Findings}

The findings revealed the following information as shown in Table 2 about the graduation numbers during the years 2009 to 2014 according to available data at public, private, and for-profit 2-year and 4-year universities in the United States. Graduation numbers during the years 2009 to 2014 revealed that public 2-year institutions had an increase of 12 institutions (1.19\%) and 499 students graduating (1.85\%) and 4-year public institutions had an increase of 14 institutions (2.18\%) and 1,853 students graduating (6.54\%) during the years 2009 to 2014. Private 2-year institutions saw a small decline of 10 institutions (-7.45\%) and 1,080 less students graduating $(-13.52 \%)$ during the same years while 4-year private institutions experienced a marginal increase during the same timeframe of 19 institutions $(1.54 \%)$ and 543 students graduating $(0.81 \%)$. For-profit 2-year and 4-years institutions saw the greatest increase, with 2-year for-profit institutions having the largest increase in actual numbers of students graduating 6,328 $(12.74 \%)$ vs. 3,535 $(22.00 \%)$ respectively and institutions $139(17.51 \%)$ vs. 129 (32.00\%) reporting data from 2009 until 2014.

Table 2. Graduation Rates for Public, Private, and For-Profit 4-year and 2-year US

Institutions.

\begin{tabular}{lcccccc}
\hline \multicolumn{1}{c}{ Variable } & Number & Sum & Minimum & Maximum & Average & Median \\
\hline 2-year Public - 2014 & 1,017 & 27,542 & 0 & 100 & 27 & 22 \\
2-year Public - 2013 & 1,021 & 27,286 & 0 & 100 & 26 & 22 \\
2-year Public - 2012 & 1,012 & 27,390 & 0 & 100 & 27 & 22 \\
2-year Public - 2011 & 1,010 & 27,660 & 0 & 100 & 27 & 22 \\
2-year Public - 2010 & 1,011 & 27,928 & 0 & 100 & 27 & 22 \\
2-year Public - 2009 & 1,005 & 27,043 & 0 & 100 & 26 & 22 \\
2-year Private - 2014 & 124 & 6,911 & 0 & 100 & 55 & 56 \\
2-year Private - 2013 & 128 & 7,480 & 0 & 100 & 58 & 60 \\
2-year Private - 2012 & 129 & 7,848 & 0 & 100 & 60 & 67 \\
2-year Private - 2011 & 124 & 7,091 & 0 & 100 & 57 & 58 \\
2-year Private - 2010 & 132 & 7,699 & 0 & 100 & 58 & 61 \\
2-year Private - 2009 & 134 & 7,991 & 0 & 100 & 59 & 63 \\
2-year For-Profit - 2014 & 926 & 56,012 & 0 & 100 & 60 & 62 \\
2-year For-Profit - 2013 & 939 & 58,512 & 0 & 100 & 62 & 64 \\
2-year For-Profit - 2012 & 906 & 56,765 & 0 & 100 & 62 & 64 \\
2-year For-Profit - 2011 & 857 & 54,157 & 0 & 100 & 63 & 64 \\
2-year For-Profit - 2010 & 814 & 51,349 & 0 & 100 & 63 & 64 \\
2-year For-Profit - 2009 & 788 & 49,684 & 0 & 100 & 63 & 64
\end{tabular}




\begin{tabular}{lcccccc} 
4-year Public - 2014 & 655 & 30,187 & 4 & 94 & 46 & 45 \\
4-year Public - 2013 & 654 & 29,705 & 2 & 93 & 45 & 44 \\
4-year Public - 2012 & 646 & 29,117 & 4 & 100 & 45 & 44 \\
4-year Public - 2011 & 641 & 28,718 & 6 & 95 & 44 & 43 \\
4-year Public - 2010 & 642 & 28,493 & 4 & 100 & 44 & 43 \\
4-year Public - 2009 & 641 & 28,334 & 2 & 93 & 44 & 43 \\
4-year Private - 2014 & 1,253 & 67,707 & 0 & 100 & 54 & 54 \\
4-year Private - 2013 & 1,254 & 68,053 & 0 & 100 & 54 & 55 \\
4-year Private - 2012 & 1,254 & 67,471 & 0 & 100 & 53 & 55 \\
4-year Private - 2011 & 1,241 & 67,391 & 0 & 100 & 54 & 55 \\
4-year Private - 2010 & 1,227 & 67,782 & 0 & 100 & 55 & 56 \\
4-year Private - 2009 & 1,234 & 67,164 & 0 & 100 & 54 & 55 \\
4-year For-Profit - 2014 & 532 & 19,598 & 0 & 100 & 36 & 34 \\
4-year For-Profit - 2013 & 515 & 18,336 & 0 & 100 & 35 & 33 \\
4-year For-Profit - 2012 & 466 & 17,143 & 0 & 100 & 36 & 34 \\
4-year For-Profit - 2011 & 445 & 16,409 & 0 & 100 & 36 & 34 \\
4-year For-Profit - 2010 & 429 & 15,797 & 0 & 100 & 36 & 33 \\
4-year For-Profit - 2009 & 403 & 16,063 & 0 & 100 & 39 & 38 \\
\hline
\end{tabular}

\section{Discussion and Conclusion}

Even though retention numbers and rates do not provide incentive for graduating students they are the measure used most often for assessing college success. While assessments are important for measuring learning, they require the ability to assess student learning effectively. Self-regulation is essential for academic success and formative selfassessments increase self-regulation behaviors, which is linked to student success. Mindfulness is also connected to student success. Student perceptions of how they will be assessed may affect how they study, their interest in learning, their expectations, and their educational accomplishments.

Pinpointing successful teachers and teaching is difficult, particular teaching approaches are more successful than others, teachers differ in the employment of teaching approaches, and first-rate teaching is linked to student success. Assessing teacher effectiveness is typically completed through student evaluations of teaching and in some cases it is the only means for assessing instructional quality. Student test performances are also used for assessing teachers even though the practice has been criticized. Teacher effectiveness is a blend of abilities, comprehension of learning theories and subject matter, ability to change teaching approaches, working in partnership with colleagues, and is teaching that encourages learning by meeting students where students are and meeting students' needs.

Graduation numbers during the years 2009 to 2014 revealed that public 2-year and 4-year institutions had a small increase of institutions and students graduating. Private 2-year institutions saw a small decline of institutions and students graduating during the same years while 4-year private institutions experienced a marginal increase during the same timeframe of institutions and students graduating. For-profit 2-year and 4-years institutions saw the greatest increase, with 2-year for-profit institutions having over $17 \%$ increase in institutions and over $12 \%$ of students graduating while 4-year for-profit institutions experienced $32 \%$ percent growth in institutions and 22\% growth in student graduating from 2009 until 2014.

\section{Implications}

The implications from this research are numerous. To begin with, ascertaining whether or not colleges are meeting the learning needs is critical for higher education. Colleges have the duty to the society to make postsecondary education a successful experience for students to be able to do well in school, to graduate, and to become what they 
want to become in life. It is important to know if students are graduating from college. Also, assessing the success of a college or the lack of success is paramount. Of equal importance is the ability to accurately assess (a) student learning - determining if students have the ability to self-regulate and be mindful and (b) teaching effectiveness-determining the appropriate teaching approaches and the best teachers. Colleges and universities need to determine if they are meeting the learning needs of students and encouraging learning. It appears from this research that for-profit colleges and universities are experiencing the most growth in graduation rates. Therefore, public and private institutions need to examine what for-profits are doing to increase student graduation rates at their respective institutions.

\section{Limitations and Delimitations}

Specific limitations and delimitations were acknowledged at the inception of this study. A discussion of these limitations is needed in analysis of the completed study. The quantitative data for this study were obtained from the 2009 to 2014 academic years of institutions that reported to IPEDS. An examination of previous or subsequent years may have yielded different results. Additionally, data were only gathered from institutions that report to IPEDS. Although the IPEDS Data Center provided large sample sizes in all sectors of institutions, the inclusion of institutions that do not report to IPEDS may have altered the results of this study. In addition, as with all self-reported data, it is possible that data were reported to IPEDS incorrectly. If this were the case, the information would yield inaccurate results.

\section{Recommendations}

It is recommended that this study be replicated to validate these findings. Further research could be conducted examining why these graduation numbers exist in the first place. Moreover, why is there more growth in for-profit institutions than in public and private institutions? It is also recommended that studies be conducted to determine if the graduation numbers for the years of 2009 to 2014 were impacted by other factors than student graduation numbers. In addition, studies could be conducted to ascertain if similar numbers exist in other countries regarding college graduations today. It is further recommended that ongoing studies be conducted to monitor graduation numbers in the United States.

\section{References}

Andrade, M. S. (2015). Teaching online: A theory-based approach to student success. Journal of Education and Training Studies, 3(5), 1-9.

Axelson, R. D., \& Flick, A. (2011). Defining student engagement. Change: The Magazine of Higher Learning, 43 (1), 38-43.

Contreras-Higuera, W. E., Martínez-Olmo, F., Rubio-Hurtado, J. M., \& Vilà-Baños, R. (2016). University students' perceptions of e-portfolios and rubrics as combined assessment tools in education courses. Journal of Educational Computing Research, 54(1), 85-107.

Dodeen, H. (2013). College students' evaluation of effective teaching: Developing an instrument and assessing its psychometric properties. Research In Higher Education Journal, 21.

Doménech-Betoret, F., \& Fortea-Bagán, M. A. (2015). Factorial validity of a questionnaire to evaluate university students' initial perception of learning evaluation. Electronic 
Journal Of Research In Educational Psychology, 13(3), 569-586.

doi:10.14204/ejrep.37.14113

Fredin, A., Fuchsteiner, P., \& Portz, K. (2015). Working toward more engaged and successful accounting students: A balanced scorecard approach. American Journal Of Business Education, 8(1), 49-62.

Huskin, P. R. (2016). Engagement strategies for increasing student writing success. Education, 136(3), 283-290.

IPEDS Data Center.(n.d.). The integrated postsecondary education data system [Database]. Retrieved from http://nces.ed.gov/ipeds (Accessed June 1, 2016).

Johnson, M. A. (2015). Tangible and intangible student success. Journal of The National Collegiate Honors Council, 16(2), 149-153.

Liu, O. L., Rios, J. A., \& Borden, V. (2015). The Effects of Motivational Instruction on College Students' Performance on Low-Stakes Assessment. Educational Assessment, 20(2), 79-94.

Korobova, N., \& Starobin, S. S. (2015). A comparative study of student engagement, satisfaction, and academic success among international and American students. Journal Of International Students, 5(1), 72-85.

Leland, M. (2015). Mindfulness and student success. Journal Of Adult Education, 44(1), 1924.

Mahlberg, J. (2015). Formative self-assessment college classes improve self-regulation and retention in first/second year community college students. Community College Journal of Research and Practice, 39(8), 772-783, doi:10.1080/10668926.2014.922134

McKinney, L., Mukherjee, M., Wade, J., Shefman, P., \& Breed, R. (2015). Community college students' assessments of the costs and benefits of borrowing to finance higher education. Community College Review, 43(4), 329-354.

Ribando, S. J., \& Evans, L. (2015). Change happens: Assessing the initial Impact of a university consolidation on faculty. Public Personnel Management, 44(1), 99-119 21p. doi: $10.1177 / 0091026014550406$

Shaffer, S. C., Eshbach, B. E.,\& Santiago-Blay, J. A. (2015). A dual approach to fostering under-prepared student success: Focusing on doing and becoming. Insight: A Journal Of Scholarly Teaching, 1079-91.

Slanger, W. D., Berg, E. A., Fisk, P. S., \& Hanson, M. G. (2015). A longitudinal cohort study of student motivational factors related to academic success and retention using the college student inventory. Journal Of College Student Retention: Research, Theory \& Practice, 17(3), 278-302.

Stelnicki, A. M., Nordstokke, D. W., \& Saklofske, D. H. (2015). Who is the successful university student? An analysis of personal resources. Canadian Journal Of Higher Education, 45(2), 214-228.

Stephan, J. L., Davis, E., Lindsay, J., Miller, S., American Institutes for, Research, National Center for Education Evaluation and Regional Assistance, \& Regional Educational Laboratory Midwest. (2015). Who will succeed and who will struggle? Predicting Early College Success with Indiana's Student Information System. REL 2015-078. Regional Educational Laboratory Midwest,

Strayhorn, T. L. (2015). Reframing academic advising for student success: From advisor to cultural navigator. NACADA Journal, 35(1), 56-63.

Sternberg, R. J. (2015). A model of institutional creative change for assessing universities as learning organizations. Creativity Research Journal, 27(3), 254-261. doi:10.1080/10400419.2015.1063874

The Higher Education Act. 20 U.S. C. §1001. (1965) 
Trucker, J. (2014). Honors and the completion agenda: Identifying and duplicating student success. Journal Of The National Collegiate Honors Council, 15(2), 69-92.

U.S. Department of Education, National Center for Education Statistics, Integrated Postsecondary Education Data System (IPEDS). (2014a). Table 326.10, Fall 2001 and Spring 2007 through Spring 2014, Graduation Rates component.

U.S. Department of Education, National Center for Education Statistics, Integrated Postsecondary Education Data System (IPEDS). (2014b). Table 360.20, Fall 2001 and Spring 2002 through Spring 2014 Graduation Rates component.

U.S. Department of Education, National Center for Education Statistics. (2015). The Condition of Education 2015.

von der Embse, N. P., \& Putwain, D. W. (2015). Examining the context of instruction to facilitate student success. School Psychology International, 36(6), 552-558.

Zapata, G. C. (2016). University students' perceptions of integrated performance assessment and the connection between classroom learning and assessment. Foreign Language Annals, 49(1), 93-104. 